\title{
Pengaruh Diameter Sengkang Terhadap Kuat Geser Balok Dengan Variasi Diameter Tulangan Sengkang 6mm, 8 Mm Dan 10 Mm
}

\author{
Agus Sugianto $^{1)}$, Andi Marini Indriani ${ }^{2)}$ \\ ${ }^{1,2)}$ Dosen Program Studi Teknik Sipil dan Perencanaan Universitas Balikpapan, \\ Email: agus.fadhil@yahoo.co.id \\ Email : marini_sabrina@yahoo.com.sg
}

\begin{abstract}
Concrete is a construction material that is important and the most dominant is needed on the building structure, to determine the strength of normal concrete structures or modification needs to be a study with a wide range of variations, including the influence of the diameter of stirrups on shear strength of the beam. This study discusses the effect of stirrups to shear beam diameter by using test objects such as concrete beams with stirrups diameter variation $6 \mathrm{~mm}, 8 \mathrm{~mm}$ and $10 \mathrm{~mm}$, the concrete strength used was $26.73 \mathrm{MPa}$ with beam dimensions of $150 \mathrm{~mm} \times 160 \mathrm{~mm} \times 300 \mathrm{~mm}$ methods used in this study is a method of testing laboratory which aims to investigate the causal relationship between each other and comparing the results. The test results concluded stirrup diameter changes effect the shear strength of the beam resulting in a decrease of the load on the beam to strong shear stirrups BG.TR.3 10mm diameter, for a distance of reinforcement stirrups owned $\leq$ BG.TR.3 minimum shear reinforcement spacing requirements. Variations diameter beam shear reinforcement stirrups to give the effect of $74.85 \%$ in the test specimen to specimen BG.TR.1 BG.TR.2. and the optimal value of the shear strength test to variations of reinforcement stirrup diameter is 10mm diameter with a shear strength value of $0.8968 \mathrm{kN} . \mathrm{m}$.
\end{abstract}

Keywords: Stirrups Diameter, Numbers Strirrups and Shear Strength Beams

\begin{abstract}
Abstrak
Beton merupakan bahan konstruksi yang penting dan paling dominan dibutuhkan pada struktur bangunan, untuk mengetahui kekuatan pada struktur beton normal atau modifikasi perlu adanya suatu penelitian dengan berbagai macam variasi, diantaranya pengaruh diameter sengkang terhadap kuat geser balok. Penelitian ini membahas pengaruh diameter sengkang terhadap geser balok dengan menggunakan benda uji berupa balok beton dengan variasi diameter sengkang 6mm, $8 \mathrm{~mm}$ dan 10mm, mutu beton yang digunakan adalah 26,73 Mpa dengan dimensi benda uji 150mm x 160mm x 300mm metode yang digunakan dalam penelitian ini adalah metode percobaan dan pengujian laboratorium yang bertujuan untuk menyelidiki hubungan sebab akibat antara satu sama lain dan membandingkan hasilnya. Hasil pengujian disimpulkan perubahan diameter sengkang mempengaruhi kekuatan geser balok sehingga terjadi penurunan terhadap beban pada balok terhadap kuat geser BG.TR.3 sengkang diameter 10mm, karena jarak tulangan sengkang yang dimiliki BG.TR.3 $\leq$ syarat jarak tulangan geser minimum. Variasi diameter tulangan sengkang terhadap geser balok memberikan pengaruh sebesar $74,85 \%$ pada benda uji BG.TR.2 terhadap benda uji BG.TR.1. dan nilai optimal pada pengujian kuat geser terhadap variasi diameter tulangan sengkang adalah diameter 10mm dengan nilai geser 0,8968 kN.m.
\end{abstract}

Kata Kunci : Diameter Sengkang, Jumlah Sengkang dan Kuat Geser Balok 


\section{Pendahuluan Latar Belakang}

Beton merupakan bahan konstruksi penting yang umum dan paling dominan digunakan dalam struktur bangunan. Beton merupakan bahan konstruksi yang mempunyai banyak kelebihan antara lain, mudah dikerjakan dengan campuran semen, pasir, agregat. Kelebihan beton yang lain adalah, ekonomis (dalam pembuatannya menggunakan bahan dasar lokal yang mudah diperoleh), dapat dibentuk sesuai dengan kebutuhan yang dikehendaki, mampu menerima kuat tekan dengan baik, tahan aus, kedap air, awet dan mudah perawatannya, maka beton sangat terkenal dan digunakan untuk struktur-struktur yang besar maupun kecil.

Mekanisme geser yang bekerja pada elemen struktur merupakan hal yang sangat penting untuk diperhatikan terlebih lagi pada komponen struktur yang rentan terhadap gaya geser seperti pada balok tinggi beton bertulang. Gaya geser umumnya tidak bekerja sendiri, tetapi terjadi kombinasi dengan lentur, torsi, atau gaya normal. Perilaku keruntuhan geser pada balok beton bertulang sangat berbeda dengan keruntuhan yang diakibatkan oleh lentur. Keruntuhan geser bersifat getas (brittle) tanpa adanya peringatan atau tanda-tanda berupa lendutan yang berarti.

Keruntuhan yang terjadi pada struktur balok lebih dominan diakibatkan oleh gaya geser. Gaya geser akan mengakibatkan terjadinya retak miring pada balok, dan setelah retak terjadi, maka mekanisme gaya geser akan disumbangkan oleh aksi pelengkung (arching action). Aksi ini dapat memberikan cadangan kapasitas yang cukup besar pada balok dalam memikul beban. Ada beberapa metode yang dapat dipakai untuk menganalisa kuat geser pada balok beton bertulang baik dengan metode empiris maupun analitis.

Rumusan masalah dalam penelitian ini adalah untuk mengetahui pengaruh variasi diameter sengkang terhadap Kuat Geser Balok Beton.

Tujuan Penelitian yang akan dicapai adalah untuk mengetahui pengaruh kekuatan struktur beton dengan menggunakan variasi diameter sengkang dan nilai optimal kuat geser pada beton dengan variasi diameter sengkang $6 \mathrm{~mm}$, $8 \mathrm{~mm}$, dan $10 \mathrm{~mm}$.

Batasan dalam penelitian adalah sebagai berikut:

a. Model balok persegi menggunakan model eksperimental bervariasi dengan lebar (b) $150 \mathrm{~mm}$. Bentang (ln) 300 $\mathrm{mm}$. serta dengan tinggi balok 160 $\mathrm{mm}$.

b. Mutu beton $\left(f c^{\prime}\right)$ penelitian adalah 23,79 MPa.

c. Mutu baja tulangan utama (fy) yang digunakan adalah $240 \mathrm{MPa}$.

d. Tulangan utama menggunakan diameter $12 \mathrm{~mm}$.

e. Mutu baja tulangan sengkang ( $f y$ ) yang digunakan adalah $240 \mathrm{MPa}$.

f. Tulangan sengkang menggunakan diameter yang bervariasi yaitu dengan diameter $6 \mathrm{~mm}, 8 \mathrm{~mm}$ dan $10 \mathrm{~mm}$.

Manfaat dari penelitian ini adalah

Memberikan pengetahuan pengaruh variasi jarak sengkang terhadap kekuatan geser pada balok beton dan pengaruh dari variasi diameter sengkang terhadap deformasi pada balok.

\section{Metode Penelitian}

\subsection{Umum}

Metode yang diterapkan dalam penelitian ini adalah metode eksperimen, yaitu penelitian yang bertujuan untuk menyelidiki hubungan sebab akibat antara satu sama lain dan membandingkan hasilnya. Pengujian yang dilakukan dalam penelitian ini meliputi pengujian bahan, dan pengujian sengkang terhadap geser balok. Untuk pengujian yang dilakukan menggunakan standart SK SNI. Model 
pengujian dibuat sesuai dengan tabel berikut:

Tabel 4.1 Penampang Benda Uji

\begin{tabular}{|c|c|c|c|}
\hline Na & Gambar Model Benda Uji & Nama & Jumlah \\
\hline 1 & 1 & BG.STR.1 & 3 \\
\hline 2 & 1 & (a, b dan c) & Buah \\
\hline 3 & & BG.STR.2 & 3 \\
\hline & & (a, b dan c) & Buah \\
\hline & & & \\
\hline & & BG.STR.3 & 3 \\
\hline
\end{tabular}

Keterangan :

BG : Balok Geser

STR/TR : Kode Balok

1, 2 dan 3 : Kode Variasi Jenis Balok

a, b dan c : Kode Penomoran masingmasing jenis balok

\subsection{Metode Pelaksanaan Pengujian Di laboratorium}

Metode pelaksanaan penelitian ini dengan melakukan uji beban terhadap balok dengan variasi diameter tulangan sengkang $6 \mathrm{~mm}, 8 \mathrm{~mm}$, dan $10 \mathrm{~mm}$. diuji tekan dilaksanakan pada umur beton 28 hari.

\section{Hasil Dan Pembahasan}

\subsection{Pengujian Benda Uji}

Pengujian benda uji dilakukan di Laboratorium bahan dan material.

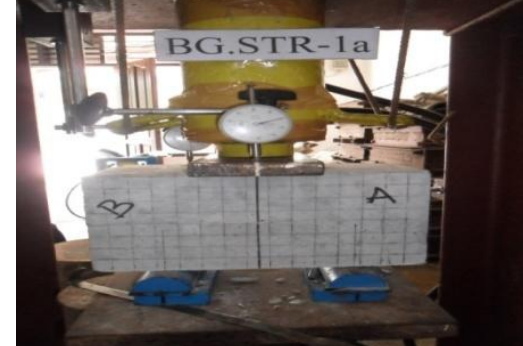

Gambar 4.1 Benda uji yang diberi beban

Tabel 4.1 Penampang Benda Uji

\begin{tabular}{|c|c|c|c|c|c|c|}
\hline \multirow{3}{*}{ No } & \multirow{3}{*}{ Kode } & \multicolumn{3}{|c|}{ Dimensi } & \multirow{2}{*}{\multicolumn{2}{|c|}{ Tulangan }} \\
\hline & & \multirow{2}{*}{\begin{tabular}{c|}
$\mathrm{b}$ \\
$\mathrm{mm}$
\end{tabular}} & \multirow{2}{*}{$\begin{array}{l}\mathrm{h} \\
\mathrm{m}\end{array}$} & \multirow{2}{*}{$\begin{array}{l}\mathrm{L} \\
\mathrm{m}\end{array}$} & & \\
\hline & & & & & Tul. Pokok & Tul. Bagi \\
\hline 1 & BG.TR.la & 150 & 160 & 170 & ø 12 & 96 \\
\hline 2 & BG.TR.1b & 150 & 160 & 170 & 912 & 96 \\
\hline 3 & BG.TR.le & 150 & 160 & 170 & $\varnothing 12$ & 96 \\
\hline 4 & BG.TR.2a & 150 & 160 & 170 & Ø12 & $\varnothing 8$ \\
\hline 5 & BG.TR. $2 b$ & 150 & 160 & 170 & $\varnothing 12$ & 08 \\
\hline 6 & BG.TR.2c & 150 & 160 & 170 & $\varnothing 12$ & 98 \\
\hline 7 & BG.TR.3a & 150 & 160 & 170 & $ø 12$ & $\varnothing 10$ \\
\hline 8 & BG.TR.3b & 150 & 160 & 170 & $\emptyset 12$ & 910 \\
\hline 9 & BG.TR.3c & 150 & 160 & 170 & $\varnothing 12$ & $\varnothing 10$ \\
\hline
\end{tabular}

Tabel 4.2 Penulangan pada Benda Uji

\begin{tabular}{|c|c|c|c|c|c|c|c|c|c|c|c|c|}
\hline \multirow[t]{2}{*}{$N_{0}$} & \multirow[t]{2}{*}{ Nama Benda $\mathrm{Jji}$} & \multirow{2}{*}{\begin{tabular}{|l|}
$f c^{\prime}$ \\
$\mathrm{Mpa}$ \\
\end{tabular}} & \multirow{2}{*}{$\begin{array}{c}E c \\
\mathrm{~m}\end{array}$} & \multirow{2}{*}{$\begin{array}{l}\text { Ie } \\
\mathrm{mm}\end{array}$} & \multirow{2}{*}{\begin{tabular}{c|c}
$a$ \\
$\mathrm{~mm}$
\end{tabular}} & $\mathrm{~L}$ & \multicolumn{2}{|c|}{$\begin{array}{l}\text { Diameter } \\
\text { Tulangan }\end{array}$} & \multicolumn{2}{|c|}{$\begin{array}{c}\text { Beban }(\mathrm{Pn}) \\
(\mathrm{kV})\end{array}$} & \multicolumn{2}{|c|}{$\begin{array}{c}\text { Defleksi }(\Delta) \\
\text { mm }\end{array}$} \\
\hline & & & & & & $\mathrm{mm}$ & Tul. Pokok & Tul Bagi & Analisa & Aktual & Analisa & Aktual \\
\hline 1 & BG.TRla & 26.73 & 24299 & 3033.057 & 85 & 170 & $\varnothing 12$ & $\varnothing 6$ & 27.4488 & 21 & 0.0762 & 0.0583 \\
\hline 2 & BG.TR $1 \mathrm{~b}$ & 26.73 & 24299 & 3033.057 & 85 & 170 & $\varnothing 12$ & $\varnothing 6$ & 27.4488 & 19 & 0.0762 & 0.0528 \\
\hline 3 & BG.TR Ic & 26.73 & 24299 & 3033.057 & 85 & 170 & $\varnothing 12$ & $\varnothing 6$ & 27.4488 & 17 & 0.0762 & 0.0472 \\
\hline 4 & BG.TR 2a & 26.73 & 24299 & 3033.057 & 85 & 170 & $\varnothing 12$ & $\varnothing 8$ & 26.1720 & 22 & 0.0727 & 0.0611 \\
\hline 5 & BG.TR $2 b$ & 26.73 & 24299 & 3033.057 & 85 & 170 & $\varnothing 12$ & 98 & 26.1720 & 23 & 0.0727 & 0.0639 \\
\hline 6 & BG.TR 2c & 26.73 & 24299 & 3033.057 & 85 & 170 & $\varnothing 12$ & $\varnothing 8$ & 26.1720 & 18 & 0.0727 & 0.0500 \\
\hline 7 & $B C$ & 26.73 & 24299 & 3033.057 & 85 & 170 & $\varnothing 12$ & $\varnothing 10$ & 24.8954 & 18 & 0.0691 & 0.0500 \\
\hline 8 & BG.TR 3b & 26.73 & 24299 & 3033.057 & 85 & 170 & $\varnothing 12$ & $\varnothing 10$ & 24.8954 & 24 & 0.0691 & 0.0653 \\
\hline 9 & BG.TR $3 \mathrm{C}$ & 26.73 & 24299 & 3033.057 & 85 & 170 & $\varnothing 12$ & $\varnothing 10$ & 24.8954 & 16 & 0.0691 & 0.0444 \\
\hline
\end{tabular}

Sumber : Data Pembuatan Benda Uji

Tabel 4.3 hasil pengujian laboratorium dengan variasi diameter tulangan sengkang diperoleh nilai rata-rata dari setiap benda uji dan digunakan sebagai pembanding untuk kuat lentur yang mengakibatkan keruntuhan geser dengan variasi diameter tulangan sengkang pada setiap model benda uji. Sehingga diperoleh hasil sebagai berikut : 
a. Hasil Pengujian kuat lentur dengan variasi diameter tulangan sengkang pada benda uji BG.TR.1 dengan nilai beban aktual rata-rata $19 \mathrm{kN}$, diperoleh nilai defleksi maksimum sebesar $0,0528 \mathrm{~mm}$. yang digunakan sebagai pembanding pangaruh variasi diameter sengkang terhadap kuat geser terhadap benda uji BG.TR.2 dan BG.TR.3.

b. Hasil Pengujian kuat lentur dengan variasi diameter tulangan sengkang pada benda uji BG.TR.2 dengan nilai beban aktual rata-rata $21 \mathrm{kN}$, sehingga diperoleh nilai defleksi maksimum sebesar $0,0583 \mathrm{~mm}$. yang digunakan sebagai pembanding pangaruh variasi diameter sengkang terhadap kuat geser terhadap benda uji BG.TR.1 dan BG.TR.3.

c. Hasil Pengujian kuat lentur dengan variasi diameter tulangan sengkang pada benda uji BG.TR.3 dengan nilai beban aktual rata-rata $19,1667 \mathrm{kN}$, diperoleh nilai defleksi maksimum sebesar 0,0532 $\mathrm{mm}$. yang digunakan sebagai pembanding pangaruh variasi diameter sengkang terhadap kuat geser terhadap benda uji BG.STR.1 dan BG.STR.2.

Hasil pengujian diatas diperoleh tabel :

Tabel 4.3 Analisa dan Hasil Pengujian Laboratorium

\begin{tabular}{|c|c|c|c|c|c|c|c|c|c|c|c|c|c|}
\hline \multirow[t]{2}{*}{1.10} & \multirow[t]{2}{*}{ Iama Benda [j] } & $f f^{\prime} f$ & $f c^{\prime}$ & Ec & Il & 0 & l & \multicolumn{2}{|c|}{$\begin{array}{l}\text { Dimmeter } \\
\text { Tulangean }\end{array}$} & \multicolumn{2}{|c|}{$\begin{array}{c}\text { Beban (Pll) } \\
(\mathrm{kI})\end{array}$} & \multicolumn{2}{|c|}{$\begin{array}{c}\text { Defleksi ( }(\Delta) \\
\text { mII }\end{array}$} \\
\hline & & I.pa & $1 . p \mathrm{p}$ & m & $\mathrm{mm}$ & mim & $\mathrm{mm}$ & Tul. Pokok & II Bagg & Andisa & Altitual : & Aandisa : & diktud \\
\hline 1 & BG. TR.1 & 20 & 26.73 & 24299 & 3033.057 & 85 & 170 & 011 & 06 & 27.4488 & 190000 & 0.072 & 0.0528 \\
\hline 2 & BG. $\mathbb{R} .2$ & 240 & 26.73 & 24299 & 3033.057 & 85 & 170 & 811 & 08 & 26.1720 & 21.000 & 0,0727 & 0.0583 \\
\hline 3 & $B G \mathbb{R} .3$ & 240 & 26.73 & 24299 & 30330.57 & 85 & 170 & 011 & 810 & 24.805: & 19.1667 & 0.0691 & 0.0332 \\
\hline
\end{tabular}

Sumber hasil pengujian laboratorium beton

\subsection{Hubungan Variasi Diameter Tulangan Sengkang Terhadap Beban}

Pada pengujian dengan variasi diameter tulangan sengkang terjadi perubahan beban yang diterima oleh setiap benda uji yang tercantum pada tabel di bawah ini.

Tabel 4.4 Hubungan Variasi Diameter Tulangan Sengkang Terhadap Beban

\begin{tabular}{|c|c|c|c|c|c|c|c|c|}
\hline \multirow{3}{*}{ No } & \multirow{3}{*}{ Kode } & \multicolumn{3}{|c|}{ Dimensi } & \multicolumn{2}{|c|}{ Tulangan } & \multirow{2}{*}{\multicolumn{2}{|c|}{$\begin{array}{c}\text { Beban }(\mathrm{Pu}) \\
(\mathrm{kN})\end{array}$}} \\
\hline & & \multirow{2}{*}{\begin{tabular}{|c|}
$\mathrm{b}$ \\
$\mathrm{mm}$ \\
\end{tabular}} & \multirow{2}{*}{\begin{tabular}{|c|}
$\mathrm{h}$ \\
$\mathrm{mm}$
\end{tabular}} & \multirow{2}{*}{\begin{tabular}{|c|}
$\mathrm{L}$ \\
$\mathrm{mm}$
\end{tabular}} & \multirow{2}{*}{\begin{tabular}{|c|} 
Tul. Pokok \\
$\varnothing$
\end{tabular}} & \multirow{2}{*}{$\begin{array}{c}\text { Tul. Bagi } \\
\varnothing\end{array}$} & & \\
\hline & & & & & & & Aktual & Analisa \\
\hline 1 & BG. TR. 1 & 150 & 160 & 170 & 12 & 6 & 19.0000 & 27.4488 \\
\hline 2 & BG. TR. 2 & 150 & 160 & 170 & 12 & 8 & 21.0000 & 26.1720 \\
\hline 3 & BG. TR. 3 & 150 & 160 & 170 & 12 & 10 & 19.1667 & 24.8954 \\
\hline
\end{tabular}

Sumber hasil pengujian laboratorium beton

Pada Tabel 4.4 hubungan variasi diameter tulangan sengkang terhadap beban sehingga dapat diuraikan sebagai berikut :

a. Benda Uji BG.TR.1 dari Tabel 4.4 hubungan variasi diameter tulangan sengkang terhadap beban dengan diameter tulangan sengkang $6 \mathrm{~mm}$, nilai beban aktual rata-rata $19 \mathrm{kN}$.

b Benda uji BG.TR.2 dari Tabel 4.4 hubungan variasi diameter tulangan sengkang terhadap beban dengan diameter tulangan sengkang 8 , meningkat $10,53 \%$ dengan nilai bebab aktual rata-rata $21 \mathrm{kN}$ dari benda uji. BG.TR.1.

c, Benda uji BG.TR.3 dari Tabel 4.4 hubungan variasi diameter tulangan sengkang terhadap beban dengan diameter tulangan sengkang 10, menurun 8,73 \% dengan nilai bebab aktual rata-rata $19,167 \mathrm{kN}$ dari benda uji BG.TR.2 dan meningkat 0,88\% dari benda uji BG.TR.1. 
Berikut grafik hubungan benda uji dengan variasi diameter tulangan sengkang dengan beban :

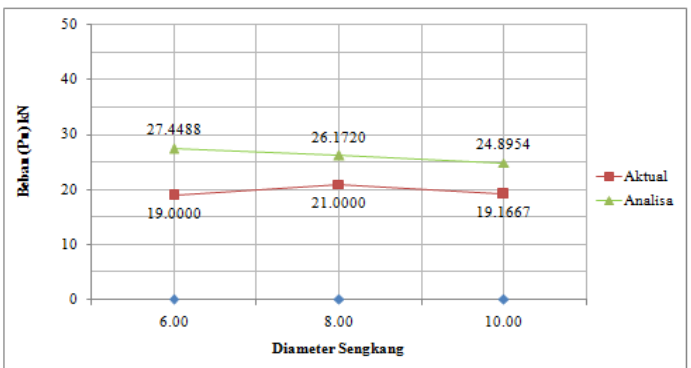

Sumber hasil pengujian laboratorium beton Gambar 4.2 Kurva Hubungan Variasi Diameter Tulangan Sengkang Dengan Beban

Gambar 4.2 kurva hubungan benda uji dengan variasi diameter tulangan sengkang dengan beban. Benda uji BG.TR.2 dengan diameter tulangan sengkang $8 \mathrm{~mm}$ diperoleh nilai beban $21 \mathrm{kN}$ meningkat $10,53 \%$ dari benda uji BG.TR.1 dengan diameter tulangan sengkang $6 \mathrm{~mm}$ diperoleh nilai beban $19 \mathrm{kN}$, menurun 8,73\% pada benda uji BG.TR.3 dengan nilai beban 19,167 $\mathrm{kN}$ dan meningkat 0,88\% dari benda uji BG.TR.1.

\subsection{Hubungan Benda Uji Dengan Momen}

Pada pengujian dilapangan dengan variasi diameter tulangan sengkang terjadi perubahan momen yang diterima oleh setiap benda uji,yang dapat dilihat pada tabel di bawah ini.

Tabel 4.5 Hubungan Benda Uji dengan Momen

\begin{tabular}{|c|c|c|c|c|c|c|c|c|c|c|}
\hline \multirow{3}{*}{$\mathrm{No}$} & \multirow{3}{*}{ Kode } & \multicolumn{3}{|c|}{ Dimensi } & \multicolumn{2}{|c|}{ Tulangan } & \multirow{2}{*}{\multicolumn{2}{|c|}{$\begin{array}{c}\text { Beban }\left(\mathrm{Pu}_{\mathrm{v}}\right) \\
(\mathrm{kN})\end{array}$}} & \multirow{2}{*}{\multicolumn{2}{|c|}{$\begin{array}{c}\operatorname{Momen}(\mathrm{M}) \\
(\mathrm{kN} \cdot \mathrm{m})\end{array}$}} \\
\hline & & \multirow[t]{2}{*}{$b$} & \multirow[t]{2}{*}{$\begin{array}{ll}\mathrm{b} & \mathrm{L}\end{array}$} & \multirow[t]{2}{*}{$\mathrm{Tu}$} & Iul. Pokok & \multirow{2}{*}{$\begin{array}{c}\text { Tul. Bagi } \\
\varnothing\end{array}$} & & & & \\
\hline & & & & & $\varnothing$ & & Alktual & Analisa & Aktual & Analisa \\
\hline 1 & BG. TR. 1 & 150 & 160 & 170 & 12 & 6 & 19.000 & 27.449 & 0.8071 & 1.1525 \\
\hline 2 & BG. TR.2 & 150 & 160 & 170 & 12 & 8 & 21.000 & 26.172 & 0.8921 & 1.0983 \\
\hline 3 & BG. TR. 3 & 150 & 160 & 170 & 12 & 10 & 19.167 & 24.895 & 0.8142 & 1.0440 \\
\hline
\end{tabular}

Sumber hasil pengujian laboratorium beton Tabel 4.5 Hubungan Benda Uji Terhadap Momen sehingga dapat diuraikan sebagai berikut : a. Hubungan Beban Dengan Momen benda uji BG.TR.1 dengan diameter tulangan sengkang 6 , nilai beban aktual rata-rata $19 \mathrm{kN}$ diperoleh nilai momen $0,8071 \mathrm{kN} . \mathrm{m}$.

b. Hubungan Beban Dengan Momen pada benda uji BG.TR.2 diameter tulangan sengkang $8 \mathrm{~mm}$, nilai beban aktual rata-rata $21 \mathrm{kN}$ diperoleh nilai momen $0,8921 \quad \mathrm{kN} . \mathrm{m}$ meningkat 10,53\% dari benda uji BG.TR.1.

c. Hubungan Beban Dengan Momen pada benda uji BG.TR.3 diameter tulangan sengkang $10 \mathrm{~mm}$, nilai beban rata-rata $19,167 \mathrm{kN}$ diperoleh nilai momen 0,8142 kN.m menurun $8,73 \%$ dari benda uji BG.TR.2 dan meningkat $0,88 \%$ dari benda uji BG.TR.1.

Kurva hubungan benda uji dengan variasi diameter tulangan sengkang terhadap momen.

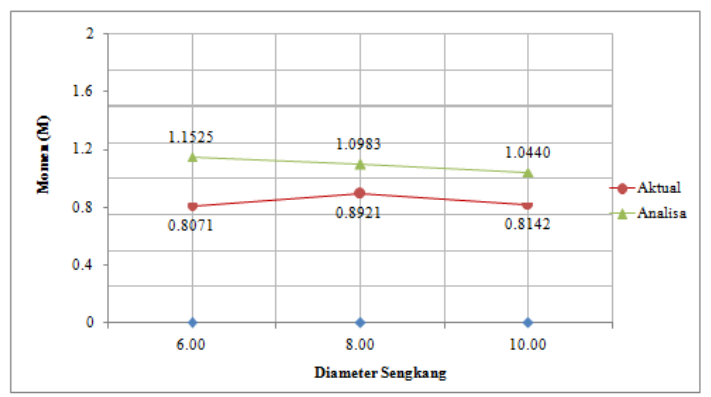

Sumber hasil pengujian laboratorium beton Gambar 4.3 Kurva Hubungan Benda Uji Dengan Momen

Gambar 4.3 kurva hubungan beban dengan momen pada benda uji BG.TR.2 diameter tulangan sengkang $8 \mathrm{~mm}$ dengan nilai beban $21 \mathrm{kN}$ diperoleh nilai momen 0,8921 kN.m meningkat $10,53 \%$ dari benda uji BG.TR.1 dengan beban $21 \mathrm{kN}$ diperoleh nilai momen $0,8071 \mathrm{kN} . \mathrm{m}$ pada benda uji BG.TR.3 dengan nilai beban $19,167 \mathrm{kN}$ diperoleh nilai momen 0,81422 kN.m meningkat $0,88 \%$ dan menurun $8,73 \%$ dari benda uji BG.TR.2. 
3.4 Hubungan Benda Uji dengan Kuat Geser Nominal Tulangan (Vs)

Pada analisa untuk penulangan geser dengan dengan memasukkan jarak sengkang serta dimensi penampang diperoleh nilai geser yang disediakan oleh benda uji untuk variasi diameter tulangan sengkang adalah sebagai berikut

Tabel 4.6 Hubungan Benda Uji dengan Geser Nominal Tulangan (Vs)

\begin{tabular}{|c|c|c|c|c|c|c|c|c|c|}
\hline \multirow{3}{*}{ No } & \multirow{3}{*}{ Kode } & \multicolumn{3}{|c|}{ Dimensi } & \multicolumn{2}{|c|}{ Tulangan } & \multirow{2}{*}{\multicolumn{2}{|c|}{$\begin{array}{c}\text { Beban }\left(\mathrm{Pu}_{\mathrm{v}}\right) \\
(\mathrm{kN})\end{array}$}} & \multirow{2}{*}{$\begin{array}{c}\text { Geser Baja } \\
\left(V_{3}\right)\end{array}$} \\
\hline & & $b$ & $\mathrm{~h}$ & $\mathrm{~L}$ & Tvl. Pokok & Tul. Bagi & & & \\
\hline & & $\mathrm{mm}$ & $\mathrm{mm}$ & $\mathrm{mm}$ & $\varnothing$ & $\varnothing$ & Aktval & Analisa & $(\mathrm{kN} \cdot \mathrm{m})$ \\
\hline 1 & BG. TR. 1 & 150 & 160 & 170 & 12 & 6 & 19.0000 & 27.4488 & 0.3342 \\
\hline 2 & BG. TR. 2 & 150 & 160 & 170 & 12 & 8 & 21.0000 & 26.1720 & 0.5843 \\
\hline 3 & BG. TR. 3 & 150 & 160 & 170 & 12 & 10 & 19.1667 & 24.8954 & 0.8968 \\
\hline
\end{tabular}

Sumber hasil pengujian laboratorium beton

Pada Tabel 4.6 Hubungan Beban dengan Geser Nominal Tulangan dapat diuraikan sebagai berikut :

a. Hubungan Beban dengan Geser Nominal Tulangan pada benda uji 1 diameter tulangan sengkang $6 \mathrm{~mm}$, nilai beban aktual rata-rata $19 \mathrm{kN}$ diperoleh nilai geser nominal tulangan 0,3342 kN.m.

b Hubungan Beban dengan Geser Nominal Tulangan pada benda uji BG.TR.2 diameter tulangan sengkang 8 , nilai beban aktual rata-rata $21 \mathrm{kN}$ diperoleh nilai geser nominal tulangan $0,5843 \mathrm{kN} . \mathrm{m}$ meningkat $74,85 \%$ dari benda uji BG.TR.1.

c Hubungan Beban Dengan Geser Nominal Tulangan pada benda uji BG.TR.3 diameter tulangan sengkang $10 \mathrm{~mm}$, nilai beban aktual rata-rata $19,167 \mathrm{kN}$. diperoleh nilai geser nominal tulangan $0,8968 \quad \mathrm{kN} . \mathrm{m}$ meningkat 53,48\% dari benda uji BG.TR. 2 dan meningkat $168,36 \%$ dari benda uji BG.TR.1.
Grafik hubungan benda uji dengan variasi diameter tulangan sengkang terhadap momen.

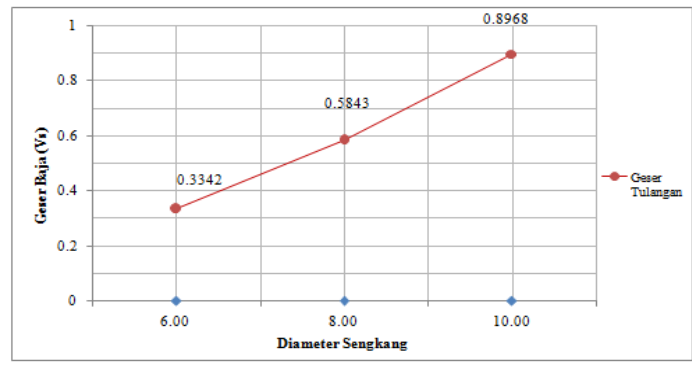

Sumber hasil pengujian laboratorium beton

Gambar 4.4 Kurva Hubungan Benda Uji

Dengan Geser Nominal Tulangan (Vs)

Gambar 4.4 kurva hubungan beban dengan geser nominal tulangan pada benda uji BG.TR.2 diameter tulangan sengkang 8 $\mathrm{mm}$ dengan nilai beban $21 \mathrm{kN}$ diperoleh nilai geser tulangan 0,5843 kN.m meningkat $74,85 \%$ dari benda uji BG.TR.1 dengan beban $19 \mathrm{kN}$ diperoleh nilai geser tulangan 0,3342 kN.m pada benda uji BG.TR.3 dengan nilai beban 19,167 diperoleh nilai geser nominal $0,8968 \mathrm{kN} . \mathrm{m}$ meningkat $168,36 \%$ dan meningkat $53,48 \%$ dari benda uji BG.TR.2.

\subsection{Hubungan Benda Uji Dengan Deformasi}

Pada pengujian dilapangan terjadi perubahan deformasi yang diterima oleh setiap benda uji,yang dapat dilihat pada tabel di bawah ini.

Tabel 4.7 Hubungan Benda Uji Dengan Deformasi

\begin{tabular}{|c|c|c|c|c|c|c|c|c|c|}
\hline \multirow{3}{*}{ No } & \multirow{3}{*}{ Kode } & \multicolumn{3}{|c|}{ Dimensi } & \multicolumn{2}{|c|}{ Tulangan } & \multirow{2}{*}{\multicolumn{2}{|c|}{$\begin{array}{c}\text { Beban ( } \mathrm{Pv}) \\
(\mathrm{kN})\end{array}$}} & \multirow{3}{*}{$\begin{array}{l}\text { Deformasi } \\
(\mathrm{mm})\end{array}$} \\
\hline & & \multirow{2}{*}{\begin{tabular}{|c|}
$b$ \\
$\mathrm{~mm}$
\end{tabular}} & \multirow{2}{*}{\begin{tabular}{c|}
$\mathrm{h}$ \\
$\mathrm{mm}$
\end{tabular}} & \multirow{2}{*}{$\mathrm{L}$} & \multirow{2}{*}{$\mid \begin{array}{c}\text { Tul. Pokok } \\
\varnothing\end{array}$} & \multirow{2}{*}{$\begin{array}{c}\text { Tul. Bagi } \\
\varnothing\end{array}$} & & & \\
\hline & & & & & & & Aktval & Analisa & \\
\hline 1 & BG. TR. 1 & 150 & 160 & 170 & 12 & 6 & 19.0000 & 27.4488 & 0.0531 \\
\hline 2 & BG. TR. 2 & 150 & 160 & 170 & 12 & 8 & 21.0000 & 26.1720 & 0.0216 \\
\hline 3 & BG. TR. 3 & 150 & 160 & 170 & 12 & 10 & 19.1667 & 24.8954 & 0.0006 \\
\hline
\end{tabular}

Sumber hasil pengujian laboratorium beton 
Pada Tabel 4.7 Hubungan Bebab Dengan Deformasi sehingga dapat diuraikan sebagai berikut :

a. Hubungan beban dengan deformasi pada benda uji BG.TR.1 diameter tulangan sengkang $6 \mathrm{~mm}$, nilai beban aktual rata-rata $19 \mathrm{kN}$ diperoleh nilai deformasi $0,0531 \mathrm{~mm}$.

b. Tabel 4.7 hubungan beban dengan deformasi pada benda uji BG.TR.2 diameter tulangan sengkang $8 \mathrm{~mm}$, dengan nilai beban aktual rata-rata21 $\mathrm{kN}$ diperoleh nilai deformasi 0,0216 mm menurun $59,41 \%$ dari benda uji BG.TR.1.

c. Tabel 4.7 hubungan beban dengan deformasi pada benda uji BG.TR.3 diameter tulangan sengkang $10 \mathrm{~mm}$, dengan nilai beban 19,67 $\mathrm{kN}$ diperoleh nilai deformasi $0,0006 \mathrm{~mm}$ menurun $97,10 \%$ dari benda uji BG.TR.2 dan menurun $98,82 \%$ dari benda uji BG.TR.1.

Berikut adalah grafik hubungan benda uji dengan variasi diameter tulangan sengkang terhadap momen.

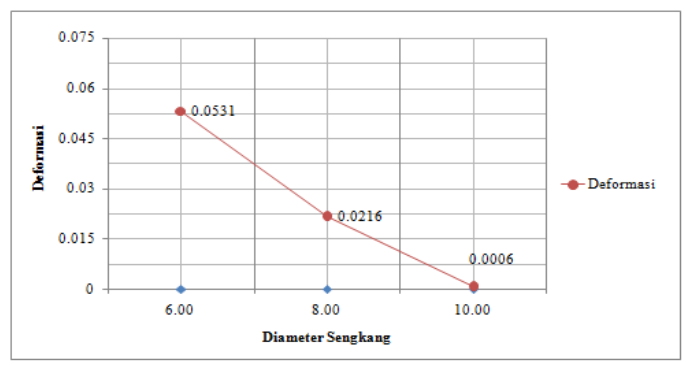

Sumber hasil pengujian laboratorium beton Gambar 4.5 Kurva Hubungan Benda Uji Dengan Deformasi

Gambar 4.5 kurva hubungan beban dengan deformasi pada benda uji BG.TR.2 diameter tulangan sengkang $8 \mathrm{~mm}$ dengan nilai beban $19 \mathrm{kN}$ diperoleh nilai deformasi 0,0216 mm menurun 59,41\% dari benda uji BG.TR.1 dengan beban 21 $\mathrm{kN}$ diperoleh nilai deformasi $0.0531 \mathrm{~mm}$ pada benda uji BG.TR.3 dengan nilai beban 19,167 diperoleh nilai deformasi 0,0006 menurun $98,82 \%$ dan menurun 97,10\% dari benda uji BG.TR.2.

\subsection{Hubungan Benda Uji Dengan Defleksi}

Pada pengujian dilapangan terjadi perubahan defleksi (peningkatan lendutan) yang diterima oleh setiap benda uji,yang dapat dilihat pada tabel di bawah ini

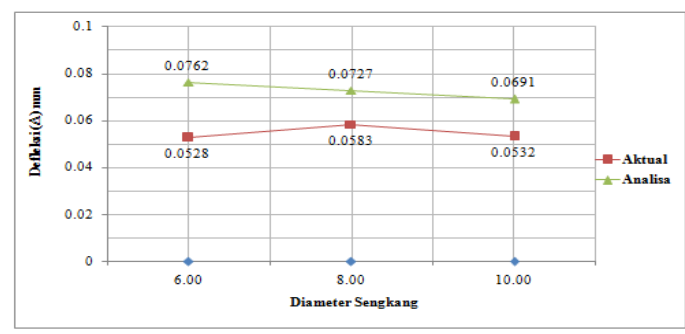

Sumber hasil pengujian laboratorium

Tabel 4.8 Hubungan Benda Uji Dengan Defleksi

Tabel 4.8 Hubungan Beban Dengan Defleksi sehingga dapat diuraikan sebagai berikut :

a. Hubungan beban dengan defleksi pada benda uji BG.TR.1 diameter tulangan sengkang $6 \mathrm{~mm}$, nilai beban $19 \mathrm{kN}$ diperoleh nilai defleksi $0,0528 \mathrm{~mm}$.

b. Hubungan beban dengan defleksi pada benda uji BG.TR.2 diameter tulangan sengkang $8 \mathrm{~mm}$, nilai beban aktual ratarata $21 \mathrm{kN}$ diperoleh nilai deformasi $0,0583 \mathrm{~mm}$ meningkat $10,53 \%$ dari benda uji BG.TR.1.

c. Hubungan beban dengan defleksi pada benda uji BG.TR.3 diameter tulangan sengkang $10 \mathrm{~mm}$, nilai beban aktual rata-rata19,167 $\mathrm{kN}$ diperoleh nilai defleksi $0,0532 \mathrm{~mm}$ menurun $8,73 \%$ dari benda uji BG.TR.2 dan meningkat 0,88\% dari benda uji BG.TR.1. 
Berikut adalah grafik hubungan benda uji dengan variasi diameter tulangan sengkang terhadap momen.

\begin{tabular}{|c|c|c|c|c|c|c|c|c|c|c|}
\hline \multirow{3}{*}{ No } & \multirow{3}{*}{ Kode } & \multicolumn{3}{|c|}{ Dimensi } & \multicolumn{2}{|c|}{ Tulangan } & \multirow{2}{*}{\multicolumn{2}{|c|}{$\begin{array}{c}\text { Beban }(\mathrm{Pu}) \\
(\mathrm{kN})\end{array}$}} & \multirow{2}{*}{\multicolumn{2}{|c|}{$\begin{array}{c}\text { Defleksi }(\Delta) \\
(\mathrm{mm})\end{array}$}} \\
\hline & & \multirow[b]{2}{*}{$\mathrm{mm}$} & \multirow{2}{*}{$\begin{array}{c}\mathrm{h} \\
\mathrm{mm}\end{array}$} & \multirow[t]{2}{*}{ L } & \multirow{2}{*}{$\begin{array}{c}\text { Tul. Pokok } \\
\varnothing\end{array}$} & \multirow{2}{*}{$\begin{array}{c}\text { Tul. Bagi } \\
\varnothing\end{array}$} & & & & \\
\hline & & & & & & & Aktual & Analisa & Aktual & Analisa \\
\hline 1 & BG. TR. 1 & 150 & 160 & 170 & 12 & 6 & 19.000 & 27.449 & 0.0528 & 0.0762 \\
\hline 2 & BG. TR. 2 & 150 & 160 & 170 & 12 & 8 & 21.000 & 26.172 & 0.0583 & 0.0727 \\
\hline 3 & BG. TR. 3 & 150 & 160 & 170 & 12 & 10 & 19.167 & 24.895 & 0.0532 & 0.0691 \\
\hline
\end{tabular}

Sumber hasil pengujian laboratorium beton

\section{Gambar 4.6 Kurva Hubungan Benda Uji Terhadap Defleksi}

Gambar 4.6 kurva hubungan beban dengan defleksi pada benda uji BG.TR.2 diameter tulangan sengkang $8 \mathrm{~mm}$ dengan nilai beban $21 \mathrm{kN}$ diperoleh nilai defleksi $0,0583 \mathrm{~mm}$ menurun $10,53 \%$ dari benda uji BG.TR.1 dengan beban $19 \mathrm{kN}$ diperoleh nilai defleksi $0.0528 \mathrm{~mm}$ pada benda BG.TR.3 dengan nilai beban 19,167 diperoleh nilai defleksi $0,0532 \mathrm{~mm}$ meningkat $0,88 \%$ dan menurun $8,73 \%$ dari benda uji BG.TR.2.

\subsection{Analisa Hasil Pembahasan}

Analisa pembahasan berisikan tentang hasil aktul pengujian di laboratorium, yang telah diuraikan pada tabel berikut :

\section{Tabel 4.9 Hasil Analisa Penelitian}

\begin{tabular}{|c|c|c|c|c|c|c|c|c|}
\hline \multirow{2}{*}{ No } & \multirow{2}{*}{ Kode } & \multicolumn{2}{|c|}{$\begin{array}{c}\text { Tulangan } \\
(\varnothing)\end{array}$} & $\begin{array}{c}\text { Beban } \\
(\mathrm{Pu})\end{array}$ & $\begin{array}{c}\text { Momen } \\
(\mathrm{M})\end{array}$ & $\begin{array}{c}\text { Geser Baja } \\
(\mathrm{Vs})\end{array}$ & $\begin{array}{c}\text { Deformasi } \\
\text { nefleksi } \\
(\Delta)\end{array}$ \\
\cline { 3 - 9 } & & Tul. Pokok & Tul. Bagi & $\mathrm{kN}$ & $\mathrm{kN.m}$ & $\mathrm{kN.m}$ & $\mathrm{kN.m}$ & $\mathrm{mm}$ \\
\hline 1 & BG. TR. 1 & $\varnothing 12$ & $\varnothing 6$ & 19.0000 & 0.8071 & 0.3342 & 0.0531 & 0.05277 \\
\hline 2 & BG. TR. 2 & $\varnothing 12$ & $\varnothing 8$ & 21.0000 & 0.8921 & 0.5843 & 0.0216 & 0.05833 \\
\hline 3 & BG. TR. 3 & $\varnothing 12$ & $\varnothing 10$ & 19.1667 & 0.8142 & 0.8968 & 0.0006 & 0.05324 \\
\hline
\end{tabular}

Sumber hasil pengujian laboratorium beton uniba

Berdasarkan Tabel 4.9 hasil analisa penelitian sehingga dapat disimpulkan mengenai perubahan diameter sengkang yang terjadi di setiap penampang : a. Hubungan benda uji dengan variasi diameter tulangan sengkang dengan beban. Benda uji BG.TR.2 dengan diameter tulangan sengkang $8 \mathrm{~mm}$ diperoleh nilai beban $21 \mathrm{kN}$ meningkat $10,53 \%$ dari benda uji 1 dengan diameter tulangan sengkang $6 \mathrm{~mm}$ nilai beban $19 \mathrm{kN}$, menurun 8,73\% pada penampang BG.TR.3 dengan nilai beban 19,167 $\mathrm{kN}$ dan meningkat 2,17\% dari penampang BG.TR.2.

b. Hubungan beban dengan momen pada benda uji BG.TR.2 diameter tulangan sengkang $8 \mathrm{~mm}$ dengan nilai beban 21 $\mathrm{kN}$ diperoleh nilai momen 0,8921 kN.m meningkat $10,53 \%$ dari benda uji BG.TR.1 dengan beban $19 \mathrm{kN}$ nilai momen $0,8071 \mathrm{kN} . \mathrm{m}$ pada benda uji BG.TR.3 dengan nilai beban 19,167 $\mathrm{kN}$ diperoleh nilai momen 0,81422 kN.m meningkat $0,88 \%$ dan menurun $8,73 \%$ dari benda uji BG.TR.2.

c. Hubungan beban dengan geser nominal tulangan pada benda uji BG.TR.2 diameter tulangan sengkang $8 \mathrm{~mm}$ dengan nilai beban $21 \mathrm{kN}$ nilai geser tulangan $0,5843 \mathrm{kN} . \mathrm{m}$ meningkat $74,85 \%$ dari benda uji BG.TR.1 dengan beban $19 \mathrm{kN}$ diperoleh nilai geser tulangan 0,3342 kN.m pada benda uji BG.TR.3 dengan nilai beban 19,167 diperoleh nilai geser nominal 0,8968 kN.m meningkat $168,36 \%$ dan meningkat $53,48 \%$ dari benda uji BG.TR.2.

d. Hubungan beban dengan deformasi pada benda uji BG.TR.2 diameter tulangan sengkang $8 \mathrm{~mm}$ dengan nilai beban $21 \mathrm{kN}$. nilai deformasi 0,0216 mm menurun $59,41 \%$ dari benda uji BG.TR.1 dengan beban $19 \mathrm{kN}$ diperoleh nilai deformasi $0.0531 \mathrm{~mm}$ pada penampang BG.TR.3 dengan nilai beban 19,167 diperoleh nilai deformasi 0,0006 menurun 98,82\% dan menurun $97,10 \%$ dari benda uji BG.TR.2. 
e. Hubungan beban dengan defleksi pada benda uji BG.TR.2 diameter tulangan sengkang $8 \mathrm{~mm}$ dengan nilai beban 21 $\mathrm{kN}$ diperoleh nilai defleksi $0,0583 \mathrm{~mm}$ meningkat $10,53 \%$ dari benda uji BG.TR.1 dengan beban $19 \mathrm{kN}$ diperoleh nilai defleksi $0.0528 \mathrm{~mm}$ pada benda Uji BG.TR.3 dengan nilai beban 19,167 diperoleh nilai defleksi $0,0532 \mathrm{~mm}$ meningkat $0,88 \%$ dan menurun $8,73 \%$ dari benda uji BG.TR.2.

\section{Kesimpulan}

Kesimpulan dari penelitian mengenai pengaruh variasi diameter tulangan sengkang terhadap kuat geser adalah :

1. Perubahan diameter sengkang dari pengujian dilaboratorium mempengaruhi kekuatan balok, sehingga terjadinya penurunan terhadap beban pada balok BG.STR.3 dengan diameter 10, karena jarak tulangan sengkang yang dimiliki BG.STR.3 $\leq$ syarat jarak tulangan geser minimum. Variasi diameter tulangan sengkang terhadap geser balok ternyata memberikan pengaruh sebesar $74,85 \%$ benda uji BG.STR.2 terhadap benda uji BG.STR.1.

2. Nilai optimal pada pengujian kuat geser terhadap variasi diameter tulangan sengkang adalah diameter 10 dengan nilai geser $0,8968 \mathrm{kN} . \mathrm{m}$

\section{Daftar Pustaka}

Anonim, 2002, Tata Cara Perhitungan Struktur Beton Untuk Bangunan Gedung SNI, Bandung, Desember 2012.

Anonim,2002, Baja Tulangan Beton,SNI 07-2052-2002,Jakarta.

Anonim, 2008,Cara Uji Slump Beton, SNI 1972:2008,Jakarta.

Dipohusodo, 1994, Struktur Beton Bertulan, Penerbit PT Gramedia Pustaka Utama, Jakarta, 10207.

Edward. G. Nawy, Tavio, \& Benny Kusuma, 2010, Beton Bertulang, Edisi ke5, Penerbit ITS Press, Surabaya 60111.

H. Alis. Asroni, 2010, Balok Dan Pelat Beton Bertulang, Penerbit Graha Ilmu, Yogyakarta 55283.

L. J. Murdock, K. M. Brook, 1981,Bahan dan Praktek Beton, Edisi ke-4, Penerbit Erlangga, Jakarta, 10420.

Sadji,2006,Material Beton Dan Persyaratannya, Penerbit ITS dan HAKI, Surabaya 60111.

Tri Mulyono, 2005, Teknologi Beton, Penerbit CV. Andi Offset, Yogyakarta 55281.

W. C. Vis, \& Gideon Kusuma,1993, Dasar Dasar Perencanaan Beton Bertulang, Penerbit Erlangga, Jakarta 13740. 